\title{
Promotion of freedom of religion or belief
}

Iffat Idris

GSDRC, University of Birmingham

22 January 2021

\section{Question}

Which countries have improved their record on protecting and promoting freedom of religion or belief and what are the reasons for doing so?

What can external actors (donor countries and multilaterals) do to encourage states to protect and promote freedom of religion or belief?

\section{Contents}

1. Summary

2. Countries showing significant improvement in FoRB

3. Other FoRB improvements

4. Monitoring and reporting

5. External pressure

6. Constructive engagement

7. References

The K4D helpdesk service provides brief summaries of current research, evidence, and lessons learned. Helpdesk reports are not rigorous or systematic reviews; they are intended to provide an introduction to the most important evidence related to a research question. They draw on a rapid deskbased review of published literature and consultation with subject specialists.

Helpdesk reports are commissioned by the UK Foreign, Commonwealth, and Development Office and other Government departments, but the views and opinions expressed do not necessarily reflect those of FCDO, the UK Government, K4D or any other contributing organisation. For further information, please contact helpdesk@k4d.info. 


\section{Summary}

Freedom of religion or belief (FoRB) is a fundamental human right. However, the general global trend in recent years is towards increased FoRB violations by both government and nongovernment actors. Notable exceptions are Sudan and Uzbekistan, which have shown significant improvement in promoting FoRB, while smaller-scale positive developments have been seen in a number of other countries. The international community is increasingly focusing on FoRB. External actors can help promote FoRB through monitoring and reporting, applying external pressure on governments (and to a lesser extent non-government entities), and through constructive engagement with both government and non-government actors. The literature gives recommendations for how each of these approaches can be effectively applied.

This review is largely based on grey (and some academic) literature as well as recent media reports. The evidence base was limited by the fact that so few countries have shown FoRB improvements, but there was wider literature on the role that external actors can play. The available literature was often gender blind (typically only referring to women and girls in relation to FoRB violations) and made negligible reference to persons with disabilities.

Freedom of religion or belief (FRB) is enshrined in Article 18 of the Universal Declaration of Human Rights (UDHR) drafted in 1948. Article 18 states (cited in Toft \& Green, 2018: 4):

Everyone has the right to freedom of thought, conscience and religion; this right includes freedom to change his religion or belief, and freedom, either alone or in community with others and in public or private, to manifest his religion or belief in teaching, practice, worship and observance.

Key findings of the review are as follows:

- Globally, the overall trend in relation to FoRB is predominantly negative, with some countries - notably India - showing significant deterioration. Major improvements were found only in Sudan and Uzbekistan, which were both upgraded from the USCIRF's ${ }^{1}$ countries of particular concern (CPCs) to the less serious special watch list (SWL).

- Sudan had a highly restrictive interpretation of Islamic law under former ruler Omar alBashir. Following his removal from power, a new draft constitutional charter protects FoRB, and the transitional government has ended the worst forms of persecution against the country's minority Christian population. In later reforms, the crime of apostasy ${ }^{2}$ was abolished, and Islam removed as the state religion. The improvement in FoRB appears to stem from the change in government, and a desire to reintegrate internationally.

- Uzbekistan had severe restrictions on FoRB under President Karimov, but his death in 2016 led to former PM Mirziyoyev taking power and the introduction of various reforms, e.g. printing and distributing bibles in the Uzbek language, allowing Friday prayers for civil servants, embracing religious education, the release of religious prisoners, and engagement with the UN and international community on FoRB. The reforms seem to be driven by the new leader's desire to gain domestic legitimacy, improve the country's international image and attract foreign investors, so as to promote economic growth.

1 United States Commission on International Religious Freedom.

2 The abandonment or renunciation of a religious or political belief or principle. 
- There have been smaller-scale positive developments with regard to FoRB in a number of other countries, e.g. repeal of anti-Ahmedi legislation in Bangladesh, provisions for official registration of Christian and Hindu marriages in Pakistan, and decline in Al-Shabaab extremist violence in Tanzania and Kenya.

- There is evidence of greater awareness of and increased focus on FoRB by the international community, e.g. the rise in special envoys for FoRB, and designation of 27 October as international FoRB day. Reasons for this include both the global rise in FoRB violations, and growing awareness of the importance of FoRB.

- External actors can play a number of roles to promote FoRB: monitoring and reporting on the situation with regard to FoRB in different countries; applying external diplomatic and political, economic and even military pressure to bring about FoRB; and engagement with government and non-government actors to promote FoRB.

- Monitoring and reporting in relation to FoRB, using primary sources, is carried out both by entities looking at all groups in society, e.g. USCIRF, and the UN Special Rapporteur on Freedom of Religion and Belief, and those focusing on specific groups, e.g. Humanists International and Open Doors (Christians). Others use mainly secondary sources, e.g. Pew Research Centre. FoRB monitoring and reporting can create pressure for reform ('name and shame'), and also helps to formulate effective responses and interventions. USCIRF reporting has more 'teeth' in that the US President must take punitive measures against countries of particular concern (CPCs).

- External pressure is primarily aimed at changing government decision-making and actions in target countries. Parliamentarians are in a good position to highlight FoRB violations, defend rights activists, and advocate for FoRB. It is important to apply pressure where it matters, and that those applying pressure be seen as legitimate actors by the population, and that pressure be consistent and sustained.

- External pressure is less effective against non-state actors such as local communities using hate speech and engaging in violence. But it could be used to promote change in influential non-state entities, e.g. banks/financial institutions managing funds of radical groups, or social media companies whose platforms are used to spread hate messages.

- Constructive engagement (based on building long-term relationships and gradual persuasion) with government officials and entities can be an effective alternative to pressure. Modalities can include dialogues, technical assistance on legislation, and training of officials, carried out by governments, multilateral organisations as well as international/national NGOs. Some general conditions for success of engagement approaches are: establishing trust and long-term commitment, identifying and engaging with relevant change agents and with relevant individuals within those agencies, and being wary of the risk of embeddedness (becoming associated with/legitimizing a violating government).

- Constructive engagement and cooperation is the more common approach taken with nongovernment entities to change broader societal intolerance and hostility. Mainly carried out by funding projects implemented by NGOs, key examples are interfaith dialogue and activities. It is important to take care in use of language (adapting this to local contexts), build broad alliances and promote FoRB for all rather than one particular group, and ensure continuous and long-term support. 


\section{Countries showing significant improvement in FoRB}

This review was only able to identify two countries showing significant improvement in promoting FoRB: Sudan and Uzbekistan.

The United States Commission on International Religious Freedom (USCIRF) is an independent, bipartisan US government advisory body, separate from the State Department, tasked with monitoring religious freedom abroad and making policy recommendations (USCIRF, 2020). Amidst an overall negative picture - notably with significant erosion of FoRB in India - the USCIRF's 2020 report highlights Sudan and Uzbekistan as countries which have shown improvement. As a result both have had their designation changed from 'countries of particular concern' or CPCs (defined as those where the government engages in or tolerates 'particularly severe' religious freedom violations) to 'special watch list' or SWLs (defined as those in which the government engages in or tolerates 'severe' violations of religious freedom) (USCIRF, 2020: 2).

\section{Sudan}

Following the creation of South Sudan in 2011, Sudan has been an overwhelmingly Muslim majority country $(90.7 \%)$ but there are still Christians (5.4\%) and other religious minorities in Sudan (USCIRF, 2020: 81). Despite the inclusion of religious freedom protections in the Interim National Constitution (INC), the government imposed a highly restrictive interpretation of Shariah (Islamic law) and both Muslims and non-Muslims who failed to comply faced harsh punishments (Idris, 2018). In practice, 'the former regime consistently and egregiously violated religious freedom (and) systematically oppressed religious minorities' (USCIRF, 2020: 81).

Former ruler Omar al-Bashir was deposed in April 2019, and in August civilian and military leaders signed a Draft Constitutional Charter for a 39-month transitional period (USCIRF, 2020: 81). The new charter 'protects freedom of religion or belief while notably excluding reference to Islam as the primary source of law, signalling a fundamental—if still ongoing—shift in the relationship between religion and state' (USCIRF, 2020: 81). In September the Justice Minister explicitly called out the former regime's marginalization of peripheral regions-where indigenous religious communities play a significant role-as the "root cause" of their respective conflicts. This was followed by Sudan signing a crucial agreement with the UN High Commissioner for Human Rights to open offices in several of those peripheral areas.

The USCIRF report notes that, despite the optimism generated by such moves, religious minorities still face many hurdles and repression. 'They (Christians) have acknowledged that the transitional government decisively ended the most egregious forms of persecution, but they insisted that it has not yet dismantled the convoluted system of zoning restrictions, bureaucratic impasses, and other obstacles that prevent them from reclaiming property, receiving formal recognition, and otherwise trusting that their situation has irrevocably changed' (USCIRF, 2020: 81). Other religious minorities_-including Shi'a Muslims, Baha'is, Hindus, and adherents of indigenous practices in peripheral areas- also remain marginalized.

Human Rights Watch reported in July 2020 that the country's Sovereign Council had passed into law several amendments to improve human rights in the country. These included abolishing 'the crime of apostasy - a person's conversion from Islam to another religion - which had carried the death penalty and has been used to target political activists, and allow non-Muslims to consume alcohol' (HRW, 2020). In late August the transitional government removed Islam as the state 
religion and agreed to a separation of religion and state. This was followed in October 2020 with Sudanese Muslim and Christian leaders signing a declaration (International Religious Freedom Round Table Declaration) agreeing to join forces and work to promote religious freedom in the country. ${ }^{3}$

With regard to the factors driving reform, the 2018 ACN Religion in the World report gives an indication of potential for this: 'Comprehensive sanctions against the country were lifted at the end of 2017 and Sudanese citizens can travel again without undue restrictions. Having survived a 20-year embargo, Sudan is now extremely eager to be removed from the US list of countries supporting international terrorism. The West may exploit the possibility of this change in status to force the Sudanese regime to grant broader freedoms to its citizens and bring about social and legal changes to enable religious, cultural and political diversity within society' (ACN, 2018: 686).

\section{Uzbekistan}

Uzbekistan is an overwhelmingly Muslim majority country: $93-94 \%$ of the population identify as Muslim (mostly Sunni, 1\% Shia), with 3.5\% Russian Orthodox and the remainder a mix of other religions and atheists (USCIRF, 2020: 84). While freedom of belief is guaranteed under the constitution, it has been limited by various regulations, notably the 1998 law on freedom of conscience which includes the obligation for religious groups to register, a ban on proselytism, and religious education limited to religious schools recognised by the state (ACN, 2018: 779).

The death in 2016 of President Islam Karimov, who had ruled the country for 27 years, led to his prime minister, Shavkat Mirziyoyev, taking power and the introduction of various reforms, including in relation to freedom of religion or belief:

- For the first time, in July 2017, Christians were granted access to the Bible in the Uzbek language, printed with state approval and distributed in 3,000 copies (ACN, 2018: 780)

- The release on parole on $8^{\text {th }}$ November 2017 of the only non-Muslim prisoner of conscience, Baptist Tohar Haydarov, who had been sentenced to ten years in prison in March 2010 for alleged drug offences (ACN, 2018: 780).

- The removal of the names of more than 16,000 people from a security blacklist of 17,000 potential Muslim religious extremists (ACN, 2018: 781).

- The approach to religious education changed: no longer viewed with suspicion, it is now deemed an indispensable tool to prevent the spread of religious fanaticism among young people and a way to rehabilitate those who fall under the influence of extremist ideology (ACN, 2018: 781).

- Some initiatives were undertaken to allow Muslims to fulfil their religious duties more easily, such as lifting restrictions on civil servants who want to participate in Friday prayers, introducing the Halal standard for food and re-establishing for the first time since 2005 the azan (call to prayer) (ACN, 2018: 781).

- The government also continued to engage closely with the United States and other international partners to improve religious freedom. The UN Special Rapporteur on

${ }^{3}$ Atit, M., 'Sudanese Christian, Muslim leaders agree to promote religious freedom', VOA News, 28 October 2020. https://www.voanews.com/africa/sudanese-christian-muslim-leaders-agree-promote-religious-freedom 
Freedom of Religion or Belief, Ahmed Shaheed, was invited to visit the country for the first time in 2017; the following year the government adopted a road map in response to his recommendations.

- Throughout 2019, the government by and large successfully enforced a ban on law enforcement authorities raiding and harassing religious communities, and in August announced the closure of the notorious Jasliq Prison, an isolated facility in the country's northwest that is notorious for torture and the incarceration of religious prisoners (USCIRF, 2020: 84-85).

- In August 2020 Mirziyoyev ordered the release of over 1,500 prisoners 'who sincerely repented of their deeds and firmly embarked on the path of correction'; these included 113 political and Muslim religious prisoners (Kashgarian, 2020).

The consensus in the literature seems to be that the reforms are driven by the new president's desire to gain domestic legitimacy, improve the country's international image and attract foreign investors, so as to promote economic growth (ACN, 2018). Critics point to the numerous restrictions on FoRB still in place. Nonetheless, the improvements were significant enough for the USCIRF to recommend Uzbekistan's designation be changed from 'country of particular concern' (CPC), which had held since 2005, to the 'special watch list' (SWL).

\section{Other FoRB improvements}

\section{Improvements in other countries}

While not as large-scale as the improvements seen in Sudan and Uzbekistan, there have been positive developments in relation to FoRB in other countries. Rather than giving these by country, they are given below based on the findings of entities which regularly monitor and report on FoRB (see also Section 4).

\section{UN Special Rapporteur on Freedom of Religion and Belief}

The Special Rapporteur's mandate includes monitoring and issuance of reports detailing the situation with regard to FoRB. The 2020 report looks at FoRB in the context of the 2030 Agenda for Sustainable Development, and argues that religious or belief minorities are at risk of 'being left behind'. It notes that several Sustainable Development Goals (SDGs) require the alleviation of the inequalities and discrimination suffered on the basis of religion or belief. The report examines the situation of religious or belief minorities in the context of the various SDGs. While presenting an overall worsening picture, e.g. increase in laws and policies restricting FoRB, denial of citizenship on the basis of religion or belief, exacerbated discrimination and violence against religious or belief minorities, it does also highlight some positive measures to promote FoRB. Key examples are:

- Criminalization of female genital mutilation and the repeal of apostasy laws in Sudan (see below).

- Repeal of anti-blasphemy legislation in Ireland, Canada, Greece and Denmark, and repeal of legislation in Bangladesh that banned the publication, sale and distribution of Ahmedi materials. 
- A ruling by the Supreme Court in India that the exclusion of women from entering all or parts of religious sites was discriminatory.

- Adoption of measures in Sindh province, Pakistan, to ban forced conversion and marriage of minors.

- Adoption by several countries of measures to combat hate crime, including legislation that recognizes religion or belief as a protected characteristic and an aggravating factor in the commission of crime, and in some cases, prescribes enhanced penalties.

- Measures undertaken by a number of countries to improve data collection and disaggregation with regard to discrimination based on religion or belief. These include setting up governmental offices, action plans or public-private partnerships with the purpose of monitoring and reporting on discrimination and incitement to hatred, to allow for the informed development of more accessible and effective justice institutions.

- Repeal of a provision in Ireland that allowed schools to use religion as a selection criterion, and development of education modules on religious diversity in Mexico for use in public institutions at federal, state and municipal levels, as well as the judiciary.

\section{Pew Research Centre}

The Pew Centre's reports look at the extent to which governments and societies around the world impinge on religious beliefs and practices. Countries are ranked on two indexes:

government restrictions, e.g. banning particular faiths; and social hostilities by private individuals, organisations or groups in society, e.g. sectarian violence. The latest tenth report covers the period 2007 to 2017. It found that the number of countries with 'very high' government restrictions on religion remained at the highest level since 2007, while harassment of religious groups was at a ten-year high in 2017 . The only improvement was seen in a category of social hostilities - interreligious tension and violence (e.g. sectarian or communal clashes between Hindus and Muslims in India). This fell markedly over the ten-year period, from 91 countries in 2007 to 57 countries in 2017 (Pew Research Centre, 2018: 7-8). The other 'improvement' noted was that, while the Middle East was still home to the highest levels of restrictions on religion, levels had declined since 2016.

\section{Religious Freedom in the World report}

The 2018 edition of Aid to the Church in Need (ACN)'s Religious Freedom in the World report assesses religious freedom for all faith groups in 196 countries. Countries are categorised under four groups: intolerance, discrimination, persecution and genocide. 'Discrimination' refers to institutionalisation of intolerance, and is usually carried out by the state, e.g. legal restrictions on evangelisation, while 'persecution' is concerned with terrorist groups and non-state actors. The only positive change given in the 2018 report is a sharp decline in Al-Shabaab militant violence in Tanzania and Kenya, meaning those countries were no longer categorised as 'persecution' countries (ACN, 2018: 7).

\section{UK All Party Parliamentary Group for International Freedom of Religion or Belief}

The UK APPG for FoRB report for 2019 on the current state of FoRB points to positive developments only in Pakistan. It notes that the new government led by Imran Khan 'seems to have improved control over extremist groups' as seen in the following (APPG, 2019: 46): 
- Aasia Bibi (a Christian woman sentenced to death for blasphemy) was finally acquitted of blasphemy charges and left the country. There were violent protests in response but the State stood firm. Khadim Hussain Rizvi, leader of the Tehrik-e-Labaik Pakistan - a group of anti-Ahmadiyya hardliners - was arrested under terrorism charges for leading protests against Bibi's acquittal.

- Pakistani authorities granted 3,500 visas to Indian Sikhs to visit the holy site of Gurdwara in Pakistan.

- In early 2019, the Supreme Court ruled that Christian marriages will now be officially registered with marriage certificates.

\section{International community and FoRB}

\section{Increased focus on FoRB}

The literature points to greater awareness and focus on FoRB by the international community. 'In the last few years the foreign policy tools, the global advocacy efforts and the international coordination to protect FoRB has been strengthened' (Petito et al, 2018: 6). The UK All Party Parliamentary Group on FoRB (APPG, 2019: 7-8) note:

There have....recently been positive moves which indicate that governments are starting to take this issue more seriously, such as the US Ministerial to Advance Religious Freedom, the growth in the number of dedicated ambassadors or special envoys for FoRB, the observance of 27 October as international FoRB day, and the designation by the United Nations General Assembly of 22 August as the international day to commemorate the victims of acts of violence based on their religion or belief.

Petersen and Marshall (2019: 5) echo this, pointing out that for many years FoRB was rarely a high priority in foreign policy and human rights circles, but there has been 'an almost explosive interest' in it in recent years, and consensus on the importance of international promotion of FoRB. They attribute this rise in interest both to the global rise in human rights violations on the grounds of religion or belief, and to 'growing awareness that religious institutions and beliefs play large roles in political, economic and social affairs in most world regions' (Petersen \& Marshall, 2019: 5).

\section{Role of external actors}

As seen in the cases of Sudan and Uzbekistan, external factors can play an important - even pivotal - role in promoting improvements in FoRB. Potential roles for the international community/external actors can broadly be divided into:

- Monitoring and reporting - monitoring the situation with regard to FoRB in different countries, and reporting on this ('naming and shaming'). This can create pressure for reform and/or prevent further violations.

- External pressure - the international community can call for reform and can apply diplomatic, economic and even military pressure to encourage this. Such approaches are largely geared towards changing government behaviour, policies and legislation.

- Engagement - external actors can engage and cooperate with government and nongovernment groups/stakeholders in the country to support their efforts to promote FoRB. 
International efforts to promote FoRB could also be categorised on the basis of target groups: approaches directed at government, and those targeting civil society/non-government actors. Both are important if FoRB violations are to end: 'Government is the main duty-bearer in relation to respecting, protecting, and promoting FoRB, and is also responsible for some of the severest violations throughout the world' (Petersen \& Marshall, 2019: 52). But governments are not the only perpetrators of FoRB violations: 'in the vast majority of countries with challenges of government discrimination and severe FoRB violations, societal hostilities against particular religious or belief communities are widespread' (Petersen \& Marshall, 2019: 60).

The different (but overlapping) roles external actors can play in promoting FoRB are discussed below.

\section{Monitoring and reporting}

Countries have reporting obligations in relation to FoRB under human rights treaties and the Universal Periodic Review process (Idris, 2018). External bodies can play a useful role in this particularly since countries are unlikely to be forthcoming about FoRB violations. Key external entities involved in monitoring and reporting on FoRB include:

- UN Special Rapporteur on Freedom of Religion and Belief

- US Department of State

- US Commission on International Religious Freedom

- Freedom House

- Aid to the Church in Need (ACN)

There are also actors engaged in monitoring and reporting on FoRB violations in relation to particular groups, e.g.:

- Humanists International (humanists, atheists and other non-believers)

- Open Doors (Christians)

- Middle East Concern (Christians)

- Shia Rights Watch (Shia Muslims)

All the above carry out reporting based on first-hand monitoring and primary source documentation. But there are others who produce useful overviews and rankings based mainly on secondary sources, e.g.:

- Pew Research Centre

- UK All Party Parliamentary Group (APPG) on Freedom of Religion or Belief

- European Parliament Intergroup on Freedom of Religion or Belief and Religious Tolerance - this publishes regular reports about violations of religious freedom and ensures that recommendations on how to tackle these violations are included in the EU's annual report on Human Rights (CIFoRB, 2018: 6).

Monitoring and reporting on FoRB violations is important to create pressure for reform ('name and shame'), but also to help formulate effective responses and interventions. 'A sound understanding of the actors, kinds, and degree of violations is key to formulating appropriate and effective interventions designed to prevent future abuses. This requires in-depth contextual knowledge and timely and credible documentation' (Petersen \& Marshall, 2019: 20). 
The USCIRF probably has more 'teeth' than the other monitoring entities, in that for countries which it designates CPC: 'the President of the United States is required to subject these countries to a series of punitive sanctions ranging from a mere expression of concern to economic isolation' (Toft \& Green, 2018: 6-7). Toft and Green (2018: 7) note that assessments of the effectiveness of this system over the years have been mixed. While some credit the CPC designation/threat of this with 'providing leverage to move recalcitrant states to act, such as Vietnam and Turkmenistan', and that, 'Public naming, shaming and blaming tends to turn up the heat on the abusers', others argue that, 'There's not a lot of evidence that a foot stomp and annual report has any diplomatic impact at all' (cited in Toft \& Green, 2018: 7).

Monitoring and report writing by (external) parliamentary bodies can also have an impact (CIFoRB, 2018: 6-7):

Report writing provides civil society and persecuted minorities with the opportunity to directly reach the ears of power. This convening also fosters connecting between different civil society groups and civil society groups and government. They also highlight the existence of a FoRB crisis, calling on governments to uphold their obligations to FoRB and provides analysis on the causes and potential solutions that government can follow.

For example, the US International Religious Freedom Caucus has organised public hearings on religious freedom violations in Bangladesh, Egypt, India, China, Pakistan and Saudi Arabia amongst others (CIFoRB, 2018: 7). Another example is the UK APPG for FoRB's report FORB in Pakistan and UK Government Policy (Feb. 2016) which highlighted persecution of Pakistani religious minorities and the failures of government immigration policy and practises (CIFoRB, 2018: 7). The report's research also led to greater attention on discriminatory material in Pakistani textbooks towards specific religious communities and to UK analysis on its funding of textbooks.

\section{External pressure}

Pressure can take different forms: diplomatic and political pressure, economic sanctions, and even military action, and its application is primarily aimed at changing government decisionmaking and actions in target countries. It is less effective against non-state actors such as local communities carrying out discrimination, using hate speech and engaging in violence. It could, however, be used to promote change in influential non-state entities, such as banks and financial institutions managing funds of radical groups, or social media companies whose platforms are used to spread hate messages, as in the case of Facebook in Myanmar (see Box 1).

The Commonwealth Initiative for Freedom of Religion or Belief (CIFoRB, 2018: 8, 11) highlight the roles that parliamentarians can play in relation to violations in other countries:

- Parliamentarians, through parliamentary questions, debates and media and social media sources, have a powerful mouthpiece to raise both urgent and systemic abuses of FoRB in domestic and international situations. This can generate greater attention on an issue and encourage public and government action to address the violations. They can also highlight potential solutions. 
- MPs can also act as international advocates for human rights (including FoRB) issues and concerns. This can take the form of international conferences and meetings and advocacy letters.

- If groups of international MPs from various countries, not just from the traditional Western powers, speak together their voice becomes greatly magnified and governments cannot brush off their concerns as Western imperialism. Regional and international forums for parliamentarians, such as the ASEAN Inter-Parliamentary Assembly and the Commonwealth Parliamentary Association, provide platforms for advocacy on human rights concerns and the ability to develop networks.

- MPs can play an important role in protecting human rights defenders, who are facing increasing challenges from authoritarian and oppressive governments. They can press their governments to provide more funding and training to human rights defenders in threatened countries. When MPs visit other countries on official delegations they should insist on meeting with FoRB human rights defenders as an integral part of their visit.

Based on available research and experiences from FoRB experts, Petersen and Marshall (2019: 55-56) identify a number of general conditions for success of external pressure to promote FoRB:

1. Pressure must be applied where it matters. Punishments and sanctions work best when target states have no other option than to comply, or when rewards are large. In practice, this means that pressure approaches work best with smaller states that have a weak economy and are dependent on the sanctioning state(s). Strong states that have a solid economy and ample opportunities to find ways to lessen the stings are obviously less susceptible to pressure. It also means that punishments need to be carried out by broadbased alliances, or very significant economies.

2. Those applying the pressure need to be seen as legitimate actors by the population. Punishments from foreign governments that are seen as illegitimate can antagonize public sentiment and encourage greater support to the government, in turn discouraging the government from changing its behaviour. Shaming campaigns that are carried out in coordination with strong local actors with a high degree of legitimacy in the community are most likely to be successful. Pressure also seems to be more effective if coming from friends and allies of the state in question.

3. Finally, pressure needs to be consistent and sustained. Political pressure can lead to changes in government human rights practices, but such changes are often short-lived.

Some argue that approaches that rely on external pressure may, at best, generate public awareness of FoRB violations and encourage governments to make (often limited or short-lived) improvements that protect FoRB. At worst, they 'name, blame and shame' a particular government to absolutely no effect 'since it is partly natural to not listen to those who would publicly embarrass you' (Seiple, 2012, cited in Petersen \& Marshall, 2019: 57). 


\section{Box 1: External pressure on non-state actors - Myanmar ${ }^{4}$}

This example illustrates the use of external pressure in relation to international or large national companies involved in, or actively supporting, FoRB violations. It relates to Facebook's alleged role in the dissemination of hate speech and incitement to violence in Myanmar and elsewhere. Various intergovernmental organisations, governments and NGOs have publicly criticised the company; a September 2018 report by the UN Fact Finding Mission on Myanmar, for instance, explicitly pointed to Facebook's role in stoking tensions in Myanmar. The NGO Burma Campaign UK published a list of corporations accused of involvement in human rights violations in Myanmar, including Facebook, for having 'consistently allowed its platform to be used to incite hatred and violence [against] minorities in Burma, in particular the Rohingya Muslim minority and Muslims in general'.

In 2018 Facebook head Mark Zuckerberg admitted that there was a hate speech problem with Facebook in Myanmar, and said it was hiring dozens of Burmese language content reviewers to better regulate hateful comment (Choudhury, 2020). The company issued an official statement in November 2018 admitting that it had not done enough to prevent its platform 'from being used to foment division and incite offline violence' in Myanmar, adding, 'We know we need to do more to ensure we are a force for good in Myanmar, and in other countries facing their own crises' (cited in Choudhury, 2020).

\section{Constructive engagement}

\section{With government}

An alternative approach is to strengthen FoRB protection through more private processes of engagement with government officials, religious leaders and other relevant stakeholders in the country of concern (Petersen \& Marshall, 2019: 57):

Such an approach assumes that long-term engagement and gradual persuasion are needed to convince governments to change course and encourage broader, long-term changes in behaviour, policies, and legislation rather than the relief of individual prisoners and short-lived changes. Such efforts may not be visible or appear in news media but experienced advocates and observers suggest that these longer-term efforts are most likely to result in change.

Modalities can include (Petersen \& Marshall, 2019: 57):

- international norm deliberation;

- bilateral dialogues;

- technical assistance to governments in drafting and implementing constitutions and other legislation;

- training of judiciaries, ministry staff and other government representatives;

- the facilitation of consultations between state and civil society, including with minorities and other groups that are vulnerable to violations.

\footnotetext{
4 The first paragraph of this write-up is based on Petersen and Marshall, 2019: 61.
} 
Governments, multilateral organisations as well as international and national NGOs can play important roles in such engagement processes. One example is the OSCE's Office for Democratic Institutions and Human Rights, which for decades has been engaged in the development of guidelines, provision of expert opinions, and review of legislation through its Panel of Experts on FoRB, always upon request from, and in close cooperation with the concerned member states (Petersen \& Marshall, 2019: 57). Another is the US NGO Search for Common Ground (see Box 2 for its project to promote FoRB in Kyrgyzstan).

Again, Petersen and Marshall (2019: 59) identify a number of general conditions for success of engagement approaches:

1. First, and foremost, is establishing trust and long-term commitment. Relational diplomacy takes time, especially when it comes to sensitive issues like FoRB. Not every government or NGO has the will, capacity, or resources for such long-term dialogue and political engagement. Furthermore, not all governments or NGOs have the legitimacy and clout to do so.

2. Second, and closely related, identification of and engagement with relevant change agents is imperative. This entails understanding the dynamics of power, decision-making, and implementation in relation to FoRB violations, e.g. who in government is responsible for violations? In this, relevant institutions are not necessarily central government, but rather local authorities, courts, law enforcement agencies, or the military.

3. The identification of change agents also demands an ability to build relations with individual change agents within these institutions, identifying those individuals who are capable of and willing to bring about change. Sometimes, engagement with the right individual is more important than engagement with the right institution. There is, however, obviously also a risk of relying too much on individuals; changes in the political environment may lead to the replacement of key partners, bringing the process at a halt.

4. A significant challenge is to consider and curb the risk of embeddedness. With trust and long-term relations comes the risk of being associated with, and even legitimizing, a violating government. At best, engagement strategies can contribute to steady transformation of restrictive environments; at worst, those working for FoRB may be 'used by the government as propaganda pieces to create the impression that there are no problems'.

\section{Box 2: Constructive engagement with government - Kyrgyzstan ${ }^{5}$}

The US NGO Search for Common Ground (SFCG) is an international NGO involved in political engagement initiatives. The organisation's project Promoting Freedom of Religion or Belief in Kyrgyzstan illustrates this approach. Through this project, the SFCG engaged with a range of governmental stakeholders, as well as religious leaders and civil society organizations, providing training, capacity-building, and advice on FoRB legislation. Among other things, SFCG assisted the State Commission on Religious Affairs in drafting new legislation, successfully revising a number of controversial articles on, for example, religious education and registration of religious organisations. In parallel, SFCG engaged with various actors in the justice sector to increase the knowledge and understanding of national and international legislation on FoRB. In cooperation

\footnotetext{
5 This write-up is based on Petersen and Marshall, 2019: 58.
} 
with the High School of Justice, Training Centre for Lawyers, the Training Centre for Prosecutor, and the Ministry of internal Affairs, a guidebook on FoRB legislation was developed and a series of training sessions were conducted for judges, prosecutors, advocates, and investigators. Finally, the organisation provided capacity-building for the Ombudsman institution to strengthen capacities to monitor FoRB violations and conduct court monitoring.

\section{With non-government actors}

Constructive engagement and cooperation is the more common approach taken to change the behaviour of non-state actors and broader societal cultures of intolerance and hostility. Danan (2012: 59), in her paper on use of public diplomacy by the United States to promote FoRB, highlights the role this can play: 'By directly engaging communities in dialogue on sometimes contentious issues, public diplomacy programs are able to account for a variety of theologies and worldviews, and they have the ability to promote positive religious freedom developments when bilateral efforts are not viable'.

Engagement with those outside government is mainly done through funding of projects and programmes implemented by non-governmental actors on the ground, e.g. international NGOs, human rights groups, religious leaders, other civil society actors. The initiatives can vary in scope and scale: some focus 'on religious communities, organisations and leaders, while others engage a broader range of different societal actors, including also secular human rights organisations, media, academia, and other relevant stakeholders' (Petersen \& Marshall, 2019: 62). Similarly, some are aimed at high-level, elite representatives and processes, others at the grassroots or local communities; some are relatively small in terms of scope and reach, a few are large-scale interventions, involving thousands of people (Petersen \& Marshall, 2019: 62).

Actual interventions can include 'encouraging interfaith councils, the launch of interfaith advocacy campaigns, and other activities aiming to influence political processes and structures, to diffusing counter-narratives in sermons and teaching, and organising sports tournaments, plays, and other socio-cultural activities to promote positive messages in the broader community' (Petersen \& Marshall, 2019: 63). Box 3 below gives the example of UK engagement with civil society actors in Pakistan to bring about legislation to register Hindu marriages.

Here too - constructive engagement with non-government actors - Petersen and Marshall (2019: 65-67) identify general conditions for ensuring success of such efforts:

- First, language is important, whether in strategies of interfaith dialogue, capacity-building and training, education, or broader awareness-raising campaigns. The language of human rights, and FoRB in particular, rings hollow and alien in many contexts, and must be adapted and adjusted to local contexts, incorporating local values, knowledge, and practices through processes of translation, vernacularisation, and localisation. Insights from research as well as many practitioners' experiences, emphasise that terms like coexistence, tolerance, dignity, and intercommunal harmony can be more useful than explicit FoRB language.

- Second, cooperation based on broad alliances seems to be most conducive for advancing FoRB and avoiding polarisation. Building broad alliances involving a broad range of different religious minorities, rather than singling out particular minorities, can minimise the risk of accusations of sectarianism and strengthen the chances of impact. Importantly, cooperation should also include non-religious actors, including secular 
human rights activists and organisations. This can support a more inclusive agenda, one that more accurately reflects the diverse needs and challenges on the ground.

- Finally, continuous and long-term support is key. Change takes time. Importantly, interventions must include follow-up to all activities. That means, for example, posttraining activities, assistance in disseminating acquired knowledge and tools among wider audiences, and funding for sustained networking activities. The missing link between meso-level involvement in new activities and broader changes often is lack of follow-up.

Danan (2012: 60-61) also suggests approaches for public diplomacy to promote FoRB:

- Engage unexpected and credible voices in promoting religious freedom.

- Employ creative media to increase awareness of and receptiveness to religious freedom issues.

- Improve information available on religious freedom

- Integrate religious freedom issues into traditional visitor and exchange programmes.

- Connect people of diverse religious backgrounds through multimedia.

Her paper includes examples of the above, as well as sample implementation ideas for each.

Petito, Berry and Mancinelli (2018: 3) stress the importance of interreligious engagement strategies, describing these as crucial policy tools to advance FoRB which create opportunities for positive interactions between individuals, create space for dialogue and to identify common ground, and thereby strengthen mutual understanding between traditionally hostile communities and improve societal cohesion. They make a number of recommendations in this regard (Petito et al, 2018: 3):

- Interreligious engagement strategies can include a variety of forms of interreligious dialogue and collaboration ranging from theological exchanges to day-to-day socializing and common social action by different religious, spiritual and philosophical groups and individuals. All these forms can be impactful in advancing FoRB depending on issues and contexts, provided that the policy design and implementation have carefully linked the local with the global level and the secular with the religious dimension.

- States should seek to facilitate and provide an infrastructure or environment to enable interreligious engagement to take place, yet, States must not monopolize this practice and must also allow religious communities themselves to organize interreligious dialogue and collaboration.

- In facilitating interreligious engagement, States must respect the human rights of participants and remain neutral and impartial in matters of FoRB. This includes not discriminating between religious communities, not seeking to coerce communities to participate against their will and not seeking to influence religious doctrine.

- The choice of language adopted during interreligious engagement activities to advance FoRB should be context dependent. In some instances, religious language may be more effective than the language of human rights.

Their key message is that religious actors should not only be seen as victims or perpetrators of FoRB violations, but as partners in building long-term strategies to advance FoRB for all and foster pluralism, social cohesion and sustainable peace (Petito et al, 2018: 11). 
The UK All Party Parliamentary Group (APPG) on FoRB produced a report in 2017 Article 18: From Rhetoric to Reality. It includes suggestions for the UK and other governments to help promote FoRB (APPG, 2017: 7-8):

- Track and audit government aid and investment to ensure it is not supporting intolerant narratives.

- Increase 'FoRB literacy' of country and thematic desk officers at home and abroad, embassy staff and ministers in relevant government departments.

- Develop a better understanding of key FoRB issues for those affected by conflict to help design effective solutions for local needs and facilitate peacebuilding.

- Work with and support civil society effectively to change cultural narratives around FoRB.

- Be wary about highlighting government involvement when advancing FoRB.

- Support positive messaging about respecting others' beliefs to help realise FoRB.

- Work with media organisations to advance FoRB and monitor hate speech and incitement to violence.

- Use alternative methods such as working with celebrities and business leaders to advance FoRB.

Based on the above, the report also makes specific recommendations for the UK government: see APPG, 2017: 8 and 51-56.

\section{Box 3: Engagement with civil society - Pakistan ${ }^{6}$}

A 14-member National Lobby Delegation (NLD) consisting of representatives of religious minorities of national repute working as writers, rights activists, lawyers, civil society members and journalists was funded by the UK Department for International Development and the British Embassy in Pakistan to lobby for safeguarding the rights of religious minorities in the country. The NLD campaigned for passage of Hindu Marriage Bill 2017 from Parliament of Pakistan and was successful in persuading the Punjab government to pass a resolution under Article 144 of the constitution relegating power to the federal government for enacting a uniform Hindu marriage Act. The act means that, for the first time in Pakistan's history, marriages between Hindus can be registered with the government. Prior to this legislation, Hindu couples risked being convicted of extramarital sex under the Zina ordinances of Pakistan, an offence which carries the potential punishment of stoning to death. Due to a lack of proof of marriage, Hindu women were also more likely to be forced into another marriage, as they could not easily prove that they were already married, and Hindu couples faced difficulty in basic activities such as opening bank accounts, applying for visas, getting national identity cards and shares of property. The establishment of the NLD is a good example of supporting groups to advocate for their own rights.

\footnotetext{
${ }^{6}$ This write-up is based on APPG, 2017: 46-47.
} 


\section{References}

ACN (2018). Religious Freedom in the World Report 2018. Aid to the Church in Need (ACN). https://religious-freedom-report.org/wp-content/uploads/2018/11/ENGLISH_RFR2018_low.pdf

APPG (2017). Article 18: From rhetoric to reality. UK All Party Parliamentary Group on Freedom of Religion or Belief. https://appgfreedomofreligionorbelief.org/media/Article-18-report-1710.pdf

APPG (2019). Commentary on the current state of Freedom of Religion or Belief 2019. UK All Party Parliamentary Group on Freedom of Religion or Belief.

https://appgfreedomofreligionorbelief.org/media/2019-Commentary-on-State-of-FORB.pdf

Bakken, K. (2020). Assessing Religious Freedom in Uzbekistan. United States Commission on International Religious Freedom (USCIRF).

https://www.uscirf.gov/sites/default/files/2020\%20Uzbekistan\%20Country\%20Update.pdf

Choudhury, A. (2020). 'How Facebook is Complicit in Myanmar's Attacks on Minorities'. The

Diplomat, 25 August 2020. https://thediplomat.com/2020/08/how-facebook-is-complicit-in-

myanmars-attacks-on-minorities/

CIFoRB (2018). Freedom of Religion or Belief - A Toolkit for Parliamentarians. Commonwealth Initiative for Freedom of Religion or Belief (CIFoRB).

https://www.birmingham.ac.uk/Documents/college-artslaw/ptr/ciforb/resources/FoRB-Toolkit.pdf

Danan, L. (2012). 'A Public Diplomacy Approach to International Religious Freedom'. Review of Faith \& International Affairs, 10:3.

https://www.tandfonline.com/doi/pdf/10.1080/15570274.2012.706024?needAccess=true

HRW (2020). 'Sudan's law reforms a positive first step'. Human Rights Watch, 16 July 2020.

https://www.hrw.org/news/2020/07/16/sudans-law-reforms-positive-first-step

Idris, I. (2018). Threats to and approaches to promote freedom of religion or belief. K4D Helpdesk Report, Institute of Development Studies, Brighton. https://gsdrc.org/wp-

content/uploads/2018/03/Threats_to_and_approaches_to_promote_freedom_of_religion_or_beli ef.pdf

Kashgarian, A. (2020). 'Observers remain sceptical as Uzbek government says religious extremism rising'. VOA News, 20 September 2020. https://www.voanews.com/extremismwatch/observers-remain-skeptical-uzbek-government-says-religious-extremism-rising

Maenza, N. \& Turkel, N. (2020). 'Uzbekistan must stay on the path of religious freedom reform.'. The Diplomat, July 2020. https://thediplomat.com/2020/07/uzbekistan-must-stay-on-the-path-ofreligious-freedom-reform/

Petersen, M. \& Marshall, K. (2019). The International Promotion of Freedom of Religion or Belief: Sketching the contours of a common framework. Danish Institute of Human Rights. https://www.humanrights.dk/sites/humanrights.dk/files/media/dokumenter/udgivelser/research/20 19/rapport_internationalpromotion_12.pdf 
Petito, F., Berry, S. \& Mancinelli, M. (2018). Interreligious Engagement Strategies: A Policy Tool to Advance Freedom of Religion or Belief. FoRB and Foreign Policy Initiative, University of Sussex. http://forbforeignpolicy.net/wp-content/uploads/2018/12/FoRBFPI-Policy-Report.pdf

Pew Research Centre (2019). A Closer Look at how Religious Restrictions have Risen Around the World. https://www.pewforum.org/2019/07/15/a-closer-look-at-how-religious-restrictionshave-risen-around-the-world/

Shaheed, A. (2020). Elimination of all Forms of Religious Intolerance. Report of the UN Special Rapporteur on Freedom of Religion or Belief (Advance Unedited Version). https://www.ohchr.org/EN/Issues/FreedomReligion/Pages/ReportFoRBandSDGs.aspx

Toft, M. \& Green, M. (2018). 'Progress on freedom of religion or belief?: An analysis of European and North American government and parliamentary initiatives'. The Review of Faith \& International Affairs, 16:4.

https://www.tandfonline.com/doi/pdf/10.1080/15570274.2018.1535084?needAccess=true

USCIRF (2020). Annual Report 2020. United States Commission on International Religious Freedom (USCIRF).

https://www.uscirf.gov/sites/default/files/USCIRF\%202020\%20Annual\%20Report_Final_42920.p df

\section{Suggested citation}

Idris, I. (2021). Promotion of freedom of religion or belief. K4D Helpdesk Report 958. Brighton, UK: Institute of Development Studies. DOI: 10.19088/K4D.2021.036

\section{About this report}

This report is based on six days of desk-based research. The K4D research helpdesk provides rapid syntheses of a selection of recent relevant literature and international expert thinking in response to specific questions relating to international development. For any enquiries, contact helpdesk@k4d.info.

K4D services are provided by a consortium of leading organisations working in international development, led by the Institute of Development Studies (IDS), with Education Development Trust, Itad, University of Leeds Nuffield Centre for International Health and Development, Liverpool School of Tropical Medicine (LSTM), University of Birmingham International Development Department (IDD) and the University of Manchester Humanitarian and Conflict Response Institute (HCRI).

This report was prepared for the UK Government's Foreign, Commonwealth and Development Office (FCDO) and its partners in support of pro-poor programmes. Except where otherwise stated, it is licensed for non-commercial purposes under the terms of the Open Government Licence v3.0. K4D cannot be held responsible for errors, omissions or any consequences arising from the use of information contained in this report. Any views and opinions expressed do not necessarily reflect those of FCDO, K4D or any other contributing organisation.

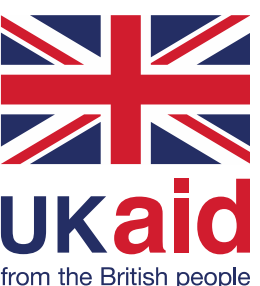

(C) Crown copyright 2021. 